\begin{tabular}{|c|c|c|}
\hline $\begin{array}{c}\text { Editorial \& Publishing Offices : } \\
\text { MaCMiLlan \& Co., LTd. } \\
\text { ST. MARTIN's STREET } \\
\text { LONDON, W.C.2 }\end{array}$ & & $\begin{array}{l}\text { Telegraphic Address : } \\
\text { PhUSIs, LeSQUARE, LoNDON } \\
\text { Telephone Number: } \\
\text { WhITEHALI } 8831\end{array}$ \\
\hline Vol. I46 & SATURDAY, AUGUST 10, I940 & No. 3693 \\
\hline
\end{tabular}

\title{
THE CHALLENGE OF SCIENCE
}

$7 \mathrm{H}$ HE widespread utilization of science in both offensive and defensive warfare has brought into fresh prominence the old question whether science is a curse or a blessing. Such a discussion cannot even in these times be dismissed as purely academic. Behind many of the problems with which we are concerned in the war effort, such as food production and factory welfare, lies the major question confronting Western society to-day, that of harnessing science to human welfare. The misuse of discoveries and inventions must not be allowed to obscure their beneficent effects. As Prof. J. C. Philip pointed out in his recent presidential address to the Society of Chemical Industry, inventions, materials and machines are not in themselves good or evil; the character of the part they play in the human drama is determined by man himself, and the tragedy is due to human weakness and failure.

On this, recent events in France may well make a vivid commentary. There is no need to subscribe to the view that widespread appreciation of science and better systematizing of human knowledge offer a panacea for the ills and maladjustments of humanity. But abandonment of extravagant claims on behalf of science does not affect the tremendous opportunities of using it as a tool for the benefit of humanity. The tragedy lies in that men have looked backward instead of forward. Realizing that neither physical science nor industry are ends in themselves and that material things cannot be allowed to dominate human life, they have sometimes thought they should be ignored-that because ends are more than means, means are of no account.

Scientific workers may well be grateful for Viscount Samuel's words on this subject in his
Messel Lecture, "Science and Civilization", before the Society of Chemical Industry on July 9. Applied science, he asserts, is worth while not only for what its achievements are in themselves but also for the sake of the ends they make possible. To blame science for the present war is unreasonable; as though there had been no warfare before the age of science. Even if the humane nations were to restrict or abolish industrial science, as an accessory to the crimes of war, we may be sure the inhuman nations would not. We cannot leave Justice with only her ancient sword to face Injustice armed with machine-gun and grenades.

A wider view, therefore, urges Viscount Samuel, will dispose of the hasty judgment that the world would be the better if it sought to discard the scientific altogether, and went back to the primitive. On the contrary, while recognizing that it should seek no monopoly in our activities, or even predominance, science, vindicated in its purposes, may rightly ask from society as a whole the conditions that will best develop its efficiency and ensure its success in tasks that are beneficent and indispensable.

A full realization of the possibilities which science has put into our hands, not merely in regard to production and leisure, but also through the lengthening of human life by the control of disease, the removal of the environmental causes in early life of many of the physical, mental and spiritual defects from which we suffer, as revealed by the new sciences of nutrition, eugenics and psychology, and the development of man's latent capacities of greatness and goodness, might well, as Sir John Orr has urged, prove a decisive factor in the development of some new system of world order. What is essential is that men should face the 
development of the new order with the same courage, the same confidence and willingness to venture as they are displaying in the prosecution of the War.

A timely and valuable contribution to the discussion has been provided by Prof. H. Levy in a recent pamphlet.* Prof. Levy takes the view that lack of courage has been shown by many educated men and women who have realized the creative power which science has placed in their hands and yet are conscious of the havoc and destruction to which that power has been turned. The turning to mysticism is a turning away from a contribution to the reasoned understanding of the forces of Nature. It is failure at a critical moment in world history to concentrate the mind and brain-power of men on vital problems the solution of which is so urgent that every ounce of thought should be directed to their analysis. It is akin to the defeatism and moral paralysis which have contributed so largely to the overthrow of France.

This, as Prof. Levy points out, is treachery indeed to science, and deals a staggering blow to humanity. When men need strength and selfreliance they are offered insecurity; when men require to face realities they are offered illusions, presented in the terms of those branches of science most remote from the common understanding, trading on popular ignorance and exploiting popular fear and interest in the mysterious. It is this confusion, for which some men of science must share the responsibility, that has hindered the forward view, the resolute shaping of policy and the fruitful impact of science on philosophy itself.

Scientific laws have a twofold aspect which is apt to be overlooked at this time of confusion. There are laws of order and laws of accident as well, and even accidents taken in the mass can be studied systematically. If philosophy is to base itself on the fullest knowledge, it must begin with the established findings of science. It must see the historical evolution of men and the tentative nature of their knowledge. It must adopt the experimental method with regard to the discovery of new generalizations, and learn how to avoid the dangers involved in false formulations of its problems.

Prof. Levy rightly emphasizes this philosophical aspect, for here can be found the corrective to the narrow perspective which is one of the dangers to be guarded against in a struggle like the present, with its tremendous demands upon our energy and

\footnotetext{
*Science-Curse or Blessing? By Prof. H. Levy. (Thinkers Forum, 4.) Pp.48. (London: Watts and Co., Ltd., 1940.) 6d. net.
}

thought. It is not the least of the merits of his pamphlet that it assists us to view the struggle itself in a wider and truer perspective which may well fortify our resolution and inspire us with fresh devotion.

The coming of this catastrophe, Prof. Levy suggests, is, from the point of view of the utilization of science, the climax to a process of human and scientific frustration that had rapidly been making itself apparent for almost a generation, just when the most striking advances were being made in almost all branches of physics, chemistry and biology.

We have now to recognize that concentration on war-time problems has shut down almost completely what might be called the cultural side, and the more barbaric side has become dominant. If this position reminds us that science itself is an aspect of social change, and must bend to the more compelling social demand, and that the direction of scientific advance must align itself with needs other than those of the internal logic of the scientific subject itself, there are at least elements of hope in the situation.

It is no matter for regret that the false idea that science is an independent discipline of its own, owing nothing and giving nothing to society, should be exploded. Moreover, some of the wartime problems have emphasized the urgent need for scientific knowledge and further research at precisely those points in the front of science where we had already become aware that the uneven advance was handicapping scientific as well as social development. The survey of man-power at present being conducted by Sir William Beveridge will unquestionably be assisted by the studies of the location of industry already conducted by P E P (Political and Economic Planning) and by the report of the Royal Commission on the Distribution of the Industrial Population. The requirements of civil defence and now of defence against invasion have underlined the arguments in such reports in favour of co-ordination and regionalism, and many important problems in local government, decentralization and the like, have been raised, the solution of which on rational lines to meet war emergencies may well clear the way for further advance later.

Besides this, evacuation questions have emphasized the need for more sociological research and may well give an impetus to many muchneeded investigations. The scientific study of the question of food supply and production is now 
being undertaken on a much more adequate basis, and the elaboration of policy and measures designed to ensure at least an adequate 'iron ration' for the whole population may not only lead to the more scientific utilization of our resources but also to the further advance of agricultural and horticultural science, and to a frontal attack on the problems of malnutrition and under-nourishment. Other problems or needs of war-time have strengthened forces making for a more intensive attack on problems of disease or other matters of public health.

Preoccupation with the effort required to prosecute the War should not therefore lead us to overlook the fact that in the profound changes involved new opportunities and possibilities are opening up before us. Vested interests or embedded prejudices that have long blocked progress are being compelled to yield before national exigencies, and we should not allow them again to hold up social or scientific advance when the War has been won. The period of scientific frustration through which we have passed is evidence of the inability of the old system to avail itself constructively of the new knowledge to usher in a new level of social life. Repression of progressive ideas, whether in Fascist or in Democratic countries, is treason to science no less than to civilization and the abiding values of man's cultural and moral heritage.

This is indeed one of our gravest dangers-that our condemnation of War itself or concentration on immediate war tasks should lead us into the company of those who cannot believe that Europe is in the throes of the birth-pangs of a new society in which they are called to play an entirely new part. The chances which the War itself offers us of ultimately building a new and better world order will not be used by those whose minds are set in old-established grooves or are afraid to face new situations and use new methods.

Whether science is a curse or a blessing depends fundamentally on whether we are prepared to meet the challenge which it throws down to us in economic and in moral affairs. The individual basis for conduct in a modern complex society is inadequate. We have to face the reorganization and reorientation of industry, of society, and of ethics itself, on a social as well as an individual besis, if our democratic institutions are to stand the strain which is thrown on them now that science and its technical applications, by binding groups together as entities, have made them socially and economically interdependent.

The issue depends largely on whether we bring to that task a width of vision and openness of mind, a firmness of purpose and a courage and comradeship commensurate with those demanded of us in this present hour of trial. It also depends on whether even now we are prepared to undertake the preliminary thought and investigation, the linking up of the war effort with the task of reconstruction, so that the opportunity to rebuild when it comes to us is not missed for lack of vision or preparation as it was two decades ago.

\section{A NEW TRANSLATION OF THE TELL EL-AMARNA LETTERS}

\section{The Tell el-Amarna Tablets}

Edited by Prof. Samuel A. B. Mercer, with the assistance of Prof. Frank Hudson Hallock in the final revision of the Manuscript. Luxor edition. 2 vols. Vol. 1. Pp. xxiv +442 . Vol. 2. Pp. iv $+443-910$. (Toronto: The Macmillan Company of Canada, Ltd., 1939). 84s. net.

$\mathrm{T}$ is fifty-three years since the famous collection 1 of cuneiform tablets known as the Tell elAmarna Letters was discovered on the site of the ancient capital of Amenophis IV, better known as Akhnaton, the 'heretic' Pharaoh. Twenty-eight years after the discovery, a careful edition of the text, with translation, notes and glossary, was produced in German by Knudtzon, with the collaboration of Weber and Ebeling. In the interval an edition, of a somewhat provisional nature, had been published by Hugo Winckler, and translated into English by Mr. J. M. P. Metcalf, in 1896. But, until the appearance of the present edition from the hand of Prof. Mercer, English scholarship has produced no independent edition of these most important documents.

This is not to say that the Tell el-Amarna Letters have been ignored by English scholars, as may be seen from such studies as the late Prof. Burney's Schweich lectures on Israelite settlement in Canaan, and Prof. S. A. Cook's admirable chapter on Syria and Palestine in the light of external evidence, in 